| Industri Kecil dalam Pusaran Pasar Global

\title{
INDUSTRI KECIL DI NEGARA BERKEMBANG DALAM PUSARAN PASAR GLOBAL
}

\section{Lasarus Jehamat ${ }^{1}$}

\begin{abstract}
Developmentalism Regime of new order placed economics as commander becoming starting point of all life aspect. The aim of this policy is to attainment of growth of the economics which at the farthest. All of the production activity later; then reduced just for attainment of economic goals. Activity of such production in this context is big industry. Its clear rationalization, all of the owner of capital inculcate its capital at various invesment type which likeliest give advantage more is passing of mechanism capital accumulate. Agriculture clearly not become choice because assumed less or do not give advantage to capitalist clan. Small and middle enterprise also less of peeped because it don't give contribution to heaping of capital. Enableness to small and middle enterprise forwards have to pay attention six step namely exacerbating of vision and goals of small and middle enterprise, repair of good infrastructure of software and also is hardware, arrangement of beneficial tariff of small and middle enterprise, intoducing social protection, support meassurement, and training and education.
\end{abstract}

Kata Kunci : Industri, Globalisasi, Kesejahteraan

${ }^{1}$ Dosen Sosiologi FISIP Undana Kupang 


\section{A. Pendahuluan}

Mendiskusikan tentang industrialisasi di Indonesia tidak lepas dari persoalan dikotomisasi pembangunan di hampir semua sektor produksi di negara kita. Dikotomisasi mudah dilihat dengan besarnya perhatian pemerintah untuk sektor usaha tertentu sementara itu sektor yang lain dianaktirikan. Sektor produksi yang diasumsikan memberikan keuntungan ekonomi yang nyata bagi pemerintah diberi ruang kebebasan untuk mengeksploitasi apa saja yang diingininya. Hal ini mengakibatkan munculnya berbagai jenis usaha produksi atas nama negara yang ditopang oleh kekuatan negara. Kasus Mobil Nasional atau Industri Pesawat Terbang adalah contoh paling sahih betapa pemerintah mencari-cari model industri yang menjadi primadonasemu, karena diasumsikan memberikan keuntungan ekonomi bagi negara.

Rezim pembangunanisme orde baru menempatkan ekonomi sebagai panglima yang menjadi titik tolak semua aspek kehidupan. Dampak dari rezim pembangunanisme ini adalah upaya pencapaian pertumbuhan ekonomi yang setinggi-tingginya. Semua kegiatan produksi kemudian direduksi hanya untuk pencapaian target ekonomi semata. Kegiatan produksi yang dimaksud dalam konteks ini adalah usaha atau industri yang padat modal. Rasionalisasinya jelas, para pemilik modal menanamkan modalnya pada berbagai jenis investasi yang paling mungkin memberikan keuntungan lebih melalui mekanisme akumulasi kapital. Pertanian jelas bukan menjadi pilihan para pemilik modal karena dianggap kurang atau malah tidak memberikan keuntungan bagi kaum kapitalis. Demikianpun, industri kecil dan menengah juga kurang begitu dilirik lantaran dianggap kurang memberikan kontribusi bagi penumpukan modal.

Krisis ekonomi yang melanda Indonesia sejak tahun 1997 sedikitnya mengubah logika berpikir pemerintah. Hal ini terjadi ketika berbagai industri padat modal yang kelihatan kokoh itu perlahan-lahan hancur karena kesulitan likuiditas. Justru industri kecil dan menengah yang selama ini dilihat sebelah mata oleh pengambil kebijakan dapat menjadi katup pengaman di tengan badai krisis melanda negara kita. Kita tidak sedang berbicara tentang teori ekonomi atau teori usaha kecil dan menengah. Yang ingin dipaparkan di sini adalah sikap apatis penagmbil kebijakan pada industri kecil dan menengah yang nyatanyata dapat bertahan menghadapi krisis tetapi tetap saja tidak diperhatikan.

Dalam beberapa hal berikut, industri kecil dan menengah selalu menjadi sektor produksi nomor dua (James \& Akrasane, 1993). Pertama, industri kecil dan menengah dianaktirikan dalam hal permodalan. Meskipun ada beberapa skema bantuan yang disiapkan oleh pemerintah untuk industri ini tetap saja jumlahnya tidak sebesar yang diperoleh oleh industri besar. Skema bantuan 
berupa pinjaman lunak misalnya terhalang oleh kendala birokrasi, syarat-syarat peminjaman dan jaminan. Kedua, pendidikan dan pelatihan. Dalam beberapa kasus, akses untuk pendidikan dan pelatihan jarang diadakan untuk para pelaku industri kecil dan menengah. Pendidikan dan pelatihan justru diadakan untuk para pelaku bisnis kelas atas dan kaum korporat kelas wahid. Ketiga, industri kecil dan menengah ruparupanya kelompok paling rentan terhadap ketersediaan bahan baku. Kelompok usaha ini jelas tidak memiliki akses untuk mengimpor bahan baku dari luar. Akibatnya mereka kalah bersaing dengan industri-industri besar. Keempat, diskriminasi juga terjagi dalam tataran akses terhadap pasar. Industri besar yang padat modal dengan kekuatan kapitalnya berupaya menjangkau pasar dunia dengan difasilitasi negara. Contoh sederhana, setiap kunjunan presiden atau menteri ke luar negeri, ketua Kamar Dagang dan Industri (Kadin), turut menyertai perjalanan kenegaraan tersebut. Sudah menjadi rahasia umum bahwa Kadin merupakan representasi dari kaum pemilik modal besar. Lalu, di mana kaum industrialis kecil berada?

\section{B. Kondisi Industri di Negara Berkembang : Kasus Indonesia}

Agar pembahasan tentang industri kecil dalam tulisan ini tidak melebar, maka di sini perlu diberi batasan tentang industri kecil.
Batasan atau definisi tentang industri kecil sampai saat ini masih berkisar seputar masalah jumlah tenaga kerja. Jadi, ukuran industri lebih banyak ditentukan oleh jumlah tenaga kerja yang bekerja pada usaha tertentu. Lempelius dan Thoma (1979:4) mendefinisikan industri sebagai usaha produksi. Mengutip United Nations, Lempelius dan Thoma membedakan usaha produksi dengan industri barang-barang jadi (industri besar). Pembedaannya didasarkan pada kriteria fungsional dan statistik. Kriteria fungsional berhubungan dengan faktor pembagian kerja dan mekanisme. Pembagian kerja dan mekanisme dalam usaha produktif relatif rendah. Pembedaan menurut statistik didasarkan pada ukuran perusahaan berdasarkan jumlah karyawan. Menurut Biro Pusat Statistik seperti dikutip Kuncoro (2007) berdasarkan jumlah tenaga kerja maka, industri dapat dibagi menjadi empat yakni industri kerajinan yang terdiri dari 1-4 karyawan, industri kecil terdiri dari 5-19 karyawan, industri sedang terdiri dari 20-99 karyawan dan industri besar terdiri dari 100 atau lebih karyawan. Menurut UU No. 9 /1995 tentang Usaha Kecil, disebutkan bahwa usaha kecil adalah kegiatan ekonomi rakyat yang memiliki hasil penjualan tahunan maksimal satu miliar dan memiliki kekayaan bersih, tidak termasuk tanah dan bangunan tempat usaha paling banyak dua ratus juta rupiah (Kuncoro, 2007). 
Indutri kecil dan menengah memiliki karakteristik yang hampir sama. Kuncoro

(2007) mengindentifikasi bebeapar karakteristik industri kecil di negara-negara berkembang terutama di Indonesia. Pertama, tidak adanya pembagian tugas yang jelas antara bidang administrasi dengan operasi. Pemilik industri kecil adalah individu perorangan yang sekaligus berperan sebagai pemilik dan pengelolah. Akibatnya, sukar dibedakan mana urusan usaha dan mana yang menjadi urusan keluarga. Data BPS pada tahun 1994 sebagaimana dikutip Kuncoro menunjukan jumlah pengusaha kecil mencapai 34,316 juta orang yang meliputi 15,635 pengusaha kecil mandiri tanpa menggunakan tenaga kerja lain, 18,227 juta orang pengusaha yang menggunakan anggota keluarga sebagai tenaga kerja serta 54 ribu orang pengusaha kecil yang memiliki tenaga kerja tetap. Kedua, rendahnya akses terhadap lembagalembaga kredit formal. Pelaku industri kecil lebih banyak mengandalkan modal sendiri dan modal keluarga lainnya. Ketiga, sebagian besar industri kecil belum memiliki status badan hukum. Dari total 124.990 industri kecil, 90,6 persen tidak memiliki akte notaris, 4,7 yang sudah memiliki akte notaris dan hanya hanya 1,7 persen yang sudah mempunyai badan hukum. Keempat, dilihat dari golongan industri, hampir sepertiga bagian dari industri kecil bergerak dikelompok usaha makanan, minuman dan tembakau, diikuti oleh kelompok industri bahan galian bukan logam, industri tekstil dan industri kayu, bambu, rotan, dan rumput.

Dalam catatan Kuncoro (2007) industri kecil berhasil bila dilihat dari jenis usaha dan daya serap tenaga kerja. Di sisi lain industri kecil kalah dalam jumlah output yang dihasilkan bila dibandingkan dengan industri besar. Kondisi ini tentu tidak dapat lepas dari kondisi obyektif yang menjadi ciri utama indusri kecil sebagaimana telah dijelaskan di atas. Ini menjadi sesuatu yang kontradiktif, sebab kalaupun unggul dalam hal jumlah jenis usaha dan daya serap tenaga kerja, tetapi dari output yang dihasilkan ternyata kalah jauh dibandingkan dengan industri besar. Itu berarti, ada sesuatu yang salah di sini.

Bagi negara dunia ketiga, terdapat beberapa alasan mengapa digalakan industrialisasi. Mountjoy (1983) mengidentifikasi empat alasan mengapa industrialisasi menjadi pilihan bagi negara dunia ketiga. Menurut Mountjoy, industrialisasi di berbagai negara berkembang erat kaitannya dengan proses pembangunan yang sedang dijalankan. Sebagai akibat dari hancurnya negara-negara pasca Perang Dunia II, maka setiap negara berupaya memulihkan kondisi perekonomiannya. Industrialisasi, menurut Mountjoy, bertujuan untuk : Pertama, menyediakan lapangan pekerjaan bagi penduduk yan jumlahnya semakin meningkat. Termasuk dalam kategori ini adalah menyediakan lapangan pekerjaan bagi buruh tani yang tidak memiliki pekerjaan akibat ketiadaan lahan. 
Kedua, untuk meningkatkan taraf hidup dendan meningkatkan pendapatan per kapita. Ketiga, untuk memperbaiki neraca pembayaran.

Dalam studinya tentang industri kecil dan kerajinan rakyat, Lempeluis dan Thoma (1979) menyebutkan beberapa kondisi yang menentukan industri kecil di desa.

1. Dikotomi antara sektor industri tradisional dengan sektor industri modern. Dikotomi industri modern dengan tradisional terjadi dalam beberapa hal, misalnya dalam hal modal, akses pemasaran, luas cakupan wilayah produksi, dan lain-lain. Akibatnya berdampak pada kualitas produk yang dihasilkan oleh kedua jenis industri ini. Produk industri tradisional biasanya terdesak ke desa. Dalam perkembangan yang sama, devisa yang mengalir ke luar, oleh industri modern, lebih banyak dipergunakan untuk membeli alat-alat produksi yang padat modal. Yang paling nyata adalah perkembangan industri modern lebih berorientasi pada upaya menacri dan menumpukan modal sebanyakbanyaknya.

2. Pengaruh kondisi kekuasaan setempat serta ketergantungan yang ditimbulkan olehnya. Perkembangan industri kecil juga dipengaruhi oleh kondisi sosial ekonomi masyarakat. Bantuan modal yang diberikan oleh pemerintah tidak dimanfaatkan secara lebih maksimal oleh masyarakat pengguna. Selain pada pemerintah, para pelaku industri kecil juga meminjamkan uang pada kaum pedagang lokal yang berjiwa rentenir. Akibanya, para pelaku industri kecil tidak dapat membentuk modal sendiri.

3. Orientasi masalah yang tidak memadai serta kurangnya ketegasan dalam realisasi kebijakan di sektor industri dan perekonomian. Upaya membantu industri kecil sebagaimana termaktub dalam pasal 33 UUD 1945 ternyata tidak terbukti, sebab pemerintah justru lebih memperhatikan kaum konglomerat. Akibatnya, kondisi industri kecil semakin terpuruk karena ketidakmampuan bersaing. Dalam konteks ini, kebijakan proteksi yang dilakukan oleh pemerintah terhadap industri kecil hanya sebagai retorika semata. Ironisnya, pemerintah lebih suka memperhatikan industri padat modal daripada mengembangkan industri yang sesuai dengan kondisi wilayah kita.

Berdasarkan uraian di atas, maka Lempeluis dan Thoma (1979) mengidentifikasi beberapa kondisi riil yang dihadapi oleh industri kecil adalah sebagai berikut : sasaran sempit, daya beli rendah, persaingan dari perusahanperusahan padat modal, 
ketergantungan pada pedagangpedangang besar setempat, kemungkinan untuk mendapat kredit tidak memadai, sedikitnya penawaran alat-alat produksi yang sesuai dengan usaha, tempat kedudukan di daerah pedesaan, kemungkinan pendidikan tidak mencukupi, kurangnya usaha penyuluhan, situasi budaya seetempat.

Gambaran keterbelakangan industri kecil dan menengah dapat dilihat pada bagan berikut ini.

Bagan 1 : Lingkaran Tak Berujung Keterbelakangan Industri Kecil

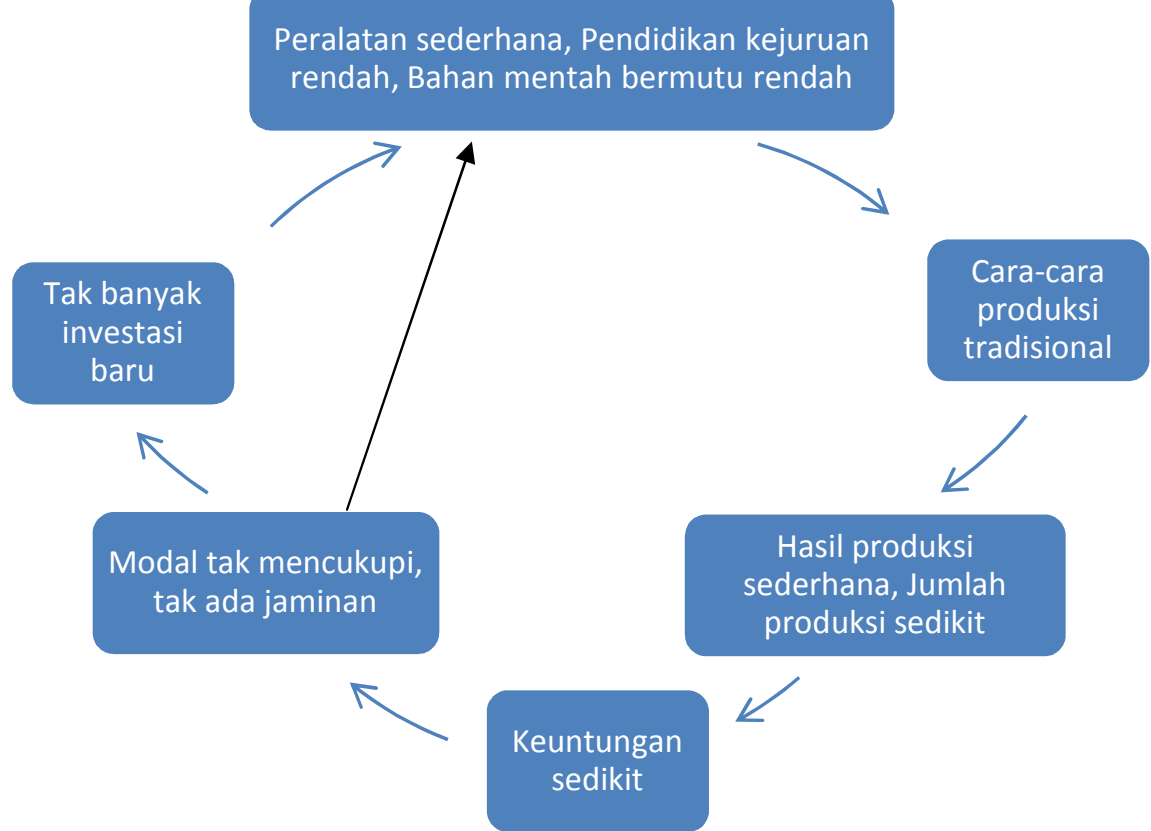

Sumber : Christian Lempelius dan Gert Thoma, Industri Kecil dan Kerajinan Rakyat, LP3ES, Jakarta, 1979 p. 5

Konsekuensi lanjutannya adalah besarnya intervensi negara terhadap dunia usaha. Pernyataan ini perlu mendapat penjelasan sebab usaha atau pengusaha yang dibantu oleh rezim yang berkuasa harus memenuhi beberapa kriteria. Pertama, usaha yang memberikan sumbangan besar bagi negara untuk mengganti penerimaan dari sektor minyak. Kedua, Industri substitusi impor yakni industri-industri yang bahan bakunya berasal dari luar tetapi dirakit di Indonesia. Ketiga, industri yang mau menerapkan mekanisme relasi produksi yang berlandaskan pancasila. Untuk kategori ketiga ini, maka dapat dipahami sepanjang kekuasaan rezim orde baru kita mendengar istilah hubungan industrial pancasila. Di bawah rezim pancasila tersebut, semua kekuatan industri tidak boleh bertentangan dengan negara.di negara kita persoalan oposisi biner antara industri besar dengan industri kecilberbagai jenis industri kecil yang hampir menyebar di seluruh Indonesia.kapitalisme pada umumnya. Hal ini mudah dipahami karena industrialisasi menjadi 
bagian penting kalau tidak ingin disebut inheren dengan perkembangan kapitalisme itu sendiri.

Menurut Kuncoro (2000), terdapat tiga alasan mengapa industri kecil dan menengah (IKM) perlu dikembangkan. Pertama, IKM menyerap banyak tenaga kerja. Kecenderungan menerap banyak tenaga kerja umumnya membuat banyak IKM juga intensif dalam menggunakan sumberdaya alam lokal. Menurut Kuncoro, karena lokasi IKM banyak terdapat di pedesaan, maka pertumbuhan IKM akan menimbulkan dampak positif terhadap peningkatan jumlah tenaga kerja, pengurangan jumlah kemiskinan, pemerataan dalam distribusi pendapatan, dan pembangunan ekonomi di pedesaan. Oleh karena itu, kebijakan pro IKM perlu dilakukan karena kontribusinya bagi perekonomian nasional. Kedua, IKM memegang peranan penting dalam ekspor nonmigas, yang pada tahun 1990 mencapai US\$1.031 juta atau menempati rangking kedua setelah ekspor dari kelompok aneka industri. Ketiga, adanya urgensi untuk struktur ekonomi yang berbentuk piramida pada PJPT I menjadi semacam "gunungan" pada PJPT II. Puncak piramida dipegang oleh usaha skala besar, dengan ciri: beroperasi dalam struktur pasar quasi-monopoli oligopolistik, hambatan masuk tinggi (adanya bea masuk, nontariff, modal, dll.), menikmati margin keuntungan yang tinggi, dan akumulasi modal cepat. Pada dasar piramida didominasi oleh usaha skala menengah dan kecil yang beroperasi dalam iklim yang sangat kompetitif, hambatan masuk rendah, margin keuntungan rendah, dan tingkat drop-out tinggi.

\section{Globalisasi Pasar : Sejarah Penundukan Industri Kecil}

Spillanne

menyebutkan bahwa globalisasi adalah pengintegrasian individuindividu ke dalam jaringan informasi dan institusi ekonomi, sosial dan politik global dengan sangat cepat melampaui ruang dan waktu. Menurut Spillane, globalisasi terutama digerakan leoh dua kekuatan besar yakni pergeseran paradigma pembangunan dari yang dipimpin negara ke pembangunan yang dipimpin pasar dan komodifikasi teknologi yang memungkinkan percepatan mobilitas barang dan jasa. Salah satu ciri khas ekonomi neoliberal adalah liberalisasi ekonomi dan globalisasi pasar. Liberalisasi ekonomi dan globalisasi pasar mengandaikan minimnya atau bahkan hilangnya kontrol negara dalam ekonomi. Pasar dibiarkan dibuka selebar-lebarnya tanpa intervensi sedikit pun oleh negara. Setiap individu boleh keluar-masuk pasar dengan syarat bisa memenuhi tuntutan pasar yang serba kompetitif. Konsekuensinya, setiap negara dilarang membatasi ruang gerak ekonomi. Globalisasi menjadikan negara sebagai arena 
luas tanpa sekat. Dunia adalah sebuah tanah lapang kompetitif.

Dengan dukungan teknologi komunikasi dan informasi, para korporat transnasional dengan mudah menjangkaui pasar dunia. Tidak hanya itu, melalui tangan lembaga-lembaga ekonomi dan keuangan global seperti WTO, IMF dan Bank Dunia, globalisasi membuat peraturan global yang tentu lebih mementingkan korporatisme global ketimbang menguntungkan ekonomi negara tertentu (Korten, 1997). Dalam logika seperti itu, perusahanperusahan asing berskala global dengan mudah keluar-masuk suatu negara tanpa hambatan apapun. Negara yang membuat hambatan baik dalam rupa tarif atau fiskal akan dilibas oleh ekonomi dunia.

Peraturan yang menghambat investasi global sebisa mungkin disingkirkan. Negara-negara dunia ketiga yang tidak memiliki fondasi ekonomi yang kuat jelas akan mengahdapi situasi dilematis; antara mengikuti logika pasar bebas atau melakukan proteksi bagi industri dalam negeri. Setiap pilihan itu memiliki konsekuensi tertentu. Pilihan untuk mengikuti kehendak pasar berakibat pada matinya pelaku pasar domestik. Ini terjadi karena memang pasar domestik tidak mampu bersaing dengan perusahan berskala global dengan kekuatan kapital yang sangat besar. Determinasi modal asing yang bersifat masif dengan jeli memanfaatkan usaha-usaha lokal untuk mempertahankan eksistensinya di suatu negara melalui hegemoni pasar. Perusahan- perusahan multinasional tersebut seolah-olah memperhatikan usaha kecil di negara-negara dunia ketiga dengan memberikan lisensi dan sebagainya. Namun di sisi lain, perusahaan-perusahaan tersebut sebenarnya sedang mempertahankan rantai produksi agar tetap bisa bertahan di negara dunia ketiga.

Pada ekstrim yang lain, pilihan untuk memproteksi pasar domestik berakibat pada dilanggarnya komitmen bersama yang sudah ditandantangani, meskipun sebenarnya proses penandatanganan kesepakatan itupun tidak dikehendaki oleh para pengambil kebijakan di negara dunia ketiga. Menarik bahwa dalam batas tertentu, para pengambil kebijakan juga turut berperan "menjual" aset negara dalam kerangka privatisasi. Pelanggaran komitmen yang dibuat oleh para antek neoliberalisme tersebut berdampak pada dikucilnya negara otonom dari percaturan ekonomi dunia.

Menurut Setiawan (2003), dampak keikutsertaan Indonesia dalam organisasi seperti World Trade Organizations (WTO) tercermin dalam beberapa konsekuensi berikut ini.

Pertama, dampak pada kebijakan. Saat ini Indonesia tidak memiliki alternatif lain selain ikut serta dalam perdagangan global. Pasar domestik Indonesia harus rela dijejali oleh produk dari negaranegara lain. Tentang hal ini, menarik apa yang digambarkan Wiryono (2003) dalam tulisannya tentang neoliberalisme yang 
menggerogoti industri pangan Indonesia dan berbagai negara dunia ketiga. Menurut Wiryono, globalisasi pasar yang sangat nampak adalah variasi produk luar di berbagai tempat perbelanjaan di Indonesia dengan label dan garansi dari negara asal barang tersebut. Keberadaan produk-produk tersebut nyaris menyingkirkan produk-produk lokal. Apa arti keberadaan berbagai macam produk asing tersebut. Dalam konteks perkembangan industri kecil dan menengah, keberadaan produk-produk dari luar tersebut menjadi gambaran marginalisasi industri kecil kita. Determinasi modal memungkinkan perusahaan transnasional memproduksi barangbarang yang laku di pasar domestik. Perusahaan atau industri kecil kita juga bisa saja memproduksi barang yang sama namun ekspansi pasarnya terhalang oleh mekanisme pemasaran yang tidak efektif. Di sini kita harus bicara tentang iklan. Perusahaan asing bisa mengiklankan produknya sehingga dikenal luas, sedangkan industri lokal memiliki keterbatasan modal dalam rangka mempromosikan produknya.

Kedua, bidang kekayaan intelektual. Kekayaan intelekstual terkait dengan produk UU No 15/2000 tentang Paten, UU No. 29/2000 tentang Varietas Tanaman, UU No. 31/2000 tentang Desain Industri. Semua produk hukum ini bermasalah karena berpotensi memarginalkan perekonomian rakyat. UU tentang varietas misalnya merugikan petani yang memiliki varietas lokal dan menguntungkan perusahaan multinasional yang memproduksi varietas dengan label "unggulan". UU tentang desain industri akan merugikan para pelaku industri kecil dan menengah, karena berbagai produk yang dibuat dianggap sebagai tiruan dari luar sehingga berpotensi mendapat delik pelanggaran hak paten.

Ketiga, sektor jasa. Berbagai layanan di bidang jasa, harus dihitung dalam kalkulasi uang. Pendidikan, kesehatan dan berbagai sektor publik lainnya seperti air bersih, listrik dan transportasi harus dibeli dengan harga yang sangat mahal. Hal ini terjadi sebagai dampak pengurangan subsudi dan privatisasi berbagai sektor jasa tersebut.

Keempat, berhubungan dengan tarif industri. Dalam beberapa kawasan industri, bea masuk ditiadakan, sehingga penanaman modal asing berjalan lancar. Modal asing bisa keluar masuk pasar domestik tanpa halangan sedikit pun. Akibatnya, industri dalam negeri tidak dapat bersaing terutama karena struktur industrinya yang sangat minim.

\section{Kebijakan Industri Kecil di Masa Mendatang}

Krisis ekonomi yang melanda Indonesia sejak 1998 telah menjadi test case eksistensi industri kecil dan menengah di Indonesia. Industri kecil dan menengah telah menjadi penyelamat bagi ribuan orang 
kehilangan pekerjaan. Industri kecil dan menengah terbukti kuat dalam menghadapi krisis ekonomi global. Persoalannya adalah apakah para pengambil kebijakan tetap menutup mata akan berbagai kekuatan yang luar biasa yang dimiliki oleh berbagai industri kerakyatan ini? Bahwa IKM memiliki kelemahan sebagaimana digambarkan diatas tidak dapat dipungkiri, namun jika melihat fungsi strategis yang dimilikinya, sulit bagi kita untuk menolak keberadaan IKM. Kuncoro (2000)menyebutkan bahwa yang perlu dilakukan ke depan dalam rangka memperkuat IKM adalah melalui berbagai macam upaya pemberdayaan, yakni :

1. Aspek managerial, yang meliputi: peningkatan produktivitas/omset/tingkat utilisasi/tingkat hunian, meningkatkan kemampuan pemasaran, dan pengembangan sumberdaya manusia.

2. Aspek permodalan, yang meliputi: bantuan modal (penyisihan 1-5\% keuntungan BUMN dan kewajiban untuk menyalurkan kredit bagi usaha kecil minimum 20\% dari portofolio kredit bank) dan kemudahan kredit (KUPEDES, KUK, KIK, KMKP, KCK, Kredit Mini/Midi, KKU).

3. Mengembangkan program kemitraan dengan besar usaha baik lewat sistem Bapak-Anak Angkat, PIR, keterkaitan huluhilir (forward linkage), keterkaitan hilir-hulu (backward linkage), modal ventura, ataupun subkontrak.

4. Pengembangan sentra industri kecil dalam suatu kawasan apakah berbentuk PIK (Pemukiman Industri Kecil), LIK (Lingkungan Industri Kecil), SUIK (Sarana Usaha Industri Kecil) yang didukung oleh UPT (Unit Pelayanan Teknis) dan TPI (Tenaga Penyuluh Industri).

5. Pembinaan untuk bidang usaha dan daerah tertentu lewat KUB (Kelompok Usaha Bersama), KOPINKRA (Koperasi Industri Kecil dan Kerajinan).

Berhubungan dengan pemberdayaan IKM, Masayuki Tanimoto (2004), dalam penelitianya tentang industri kecil di Jepang disebutkan bahwa perhatian yang lebih bagi perkembangan IKM di Jepang berdampak besar dalam peningkatan produktivitas IKM di sana. Di tengah perkembangan industri berskala besar, Jepang ternyata masih memperhatikan secara serius keberadaan industri rumah tangga. Caranya adalah melalui pemberian insentif bagi IKM agar dapat bersaing dengan IKM lain dalam menyediakan suku cadang bagi industri berskala besar.

Dalam sebuah laporang penelitian tentang industri di Vietnam, Kenichi Ohno (2004) menyebutkan beberapa rekomendasi yang perlu diupayakan untuk memberdayakan IKM diantaranya sebagaimana tertera dalam bagan berikut ini. 


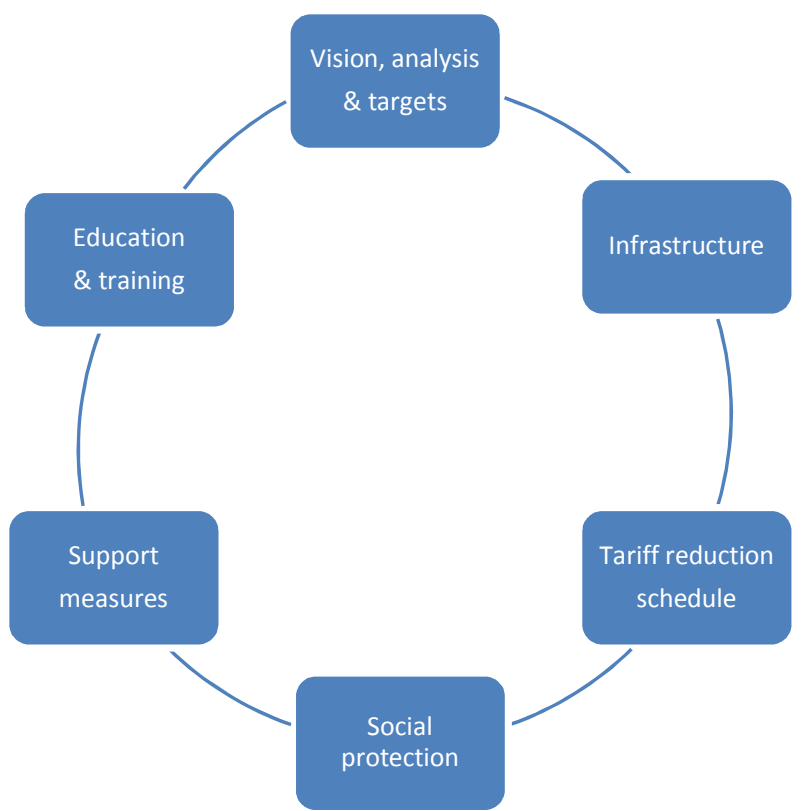

Sumber : Kenichi Ohno, 2004 : 28

Pemberdayaan terhadap IKM ke depan harus memperhatikan enam langkah yakni penajaman target dan visi IKM, perbaikan infrastruktur baik perangkat lunak maupun perangkat keras, pengaturan tarif yang menguntungkan IKM, harus memiliki sistem perlindungan sosial, support meassurement, dan pendidikan dan pelatihan. Keenam hal ini dianggap penting bagi perkembangan IKM. Dalam konteks di Indonesia, keenam hal di atas nyaris tidak pernah diperhatikan sama sekali. Pemerintah kita lebih cenderung mengakomodir kepentingan kaum kapitalis komprador yang memiliki modal besar dan tidak memiliki komitmen bagi negara ini.

Menurut Kuncoro (2000), memang pembinaan dan pemberdayaan terhadap Ikm sudah dilakukan selama ini, hanya saja pemebrdayaan yang dilakukan masih bersifat sekotral dan parsial. Akibatnya, setiap IKM tidak memiliki keterhubungan dengan IKM yang lain. Pembinaan IKM masih terkotak-kotak dalam beberapa sektor. Akibatnya adalah ketidakjelasan arah pembinaan dan tidak adanya indikator yang seragam tentang keberhasilan IKM. Karena tidak memiliki indikator yang seragam maka sering dinilai IKM tidak memiliki kontribusi atau kaulupun memiliki kontribusi, maka kontribusinya bagi perekonomian nasional sangat kecil. Tawaran untuk mendirikan pusat informasi IKM menjadi menarik agar pelaku usaha kecil dapat memeperoleh gambaran baik tentang IKM maupun tentang perkembangan perekonomian secara keseluruhan. 


\section{E. Simpulan}

Globalisasi pada dirinya memiliki watak ganda. Bagi yang telah siap, globalisasi dapat menjadi berkah, sebaliknya bagi yang belum siap, globalisasi dapat menjadi mala petaka. Untuk konteks Indonesia, terutama pada masa orde baru, globaliasi ekonomi hanya berlaku untuk industri padat modal, sebab industri seperti ini memberikan keuntungan ekonomis bagi perekonomian nasional. IKM dianggap sebagai penghalang pertumbuhan, dan oleh karena itu tidak perlu diperhatikan dan bila perlu disingkirkan.

Krisis ekonomi yang melanda Indonesia sejak satu dasawarsa lalu membalik logika seperti itu. Justru IKM telah membuktikan dirinya bisa bertahan dalam gempuran globalisasi dan berdaya tahan kuat dalam menghadapi tekanan krisis finansial. Pemerintah perlu memikirkan kembali kebijakan IKM, sebab di Indonesia, industri kecil dan menengah cukup banyak dan dijadikan penopang baik ekonomi keluarga maupun ekonomi nasional.

Upaya-upaya pemberdayaan perlu dilakukan. Berbagai langkah pemberdayaan seperti pembenahan manajemen, SDM, aturan, tarif dan lain-lain dianggap mampu membuat IKM bertahan dan dijadikan andalan dalam perekonomian nasional. Industri pada modal memang perlu, tetapi dalam konteks Indonesia yang memiliki komposisi penduduk usia kerja yang besar, industri kecil dan menengah dapat dijadikan katup bagi upaya penyerapan tenaga kerja. Dalam beberapa kasus, IKM telah menjadi tempat tumpuan terakhir ketika seseorang diberhentikan dari tempat kerjanya. Persoalannya sekarang adalah apakah pemerintah memiliki kemauan politik untuk menempatkan IKM sebagai basis utama perkembangan industri di tanah air.

\section{Daftar Pustaka}

James Kenneth dan Narongchai Akrasanee.1993, Aspek-Aspek Finansial Usaha Kecil dan Menengah, LP3ES, Jakarta

Korten David C., 1997, When Corporations Rule the World (Bila Korporasi Menguasai Dunia), Professionals Books, Jakarta Kuncoro Mudrajad, 2007, Ekonomika Industri Indonesia, Andi Yogyakarta

Kuncoro, Mudrajat 2000. “Usaha Kecil di Indonesia: Profil, Masalah dan Strategi Pemberdayaan", Makalah yang disajikan dalam Studium Generale dengan topik "Strategi Pemberdayaan Usaha Kecil di Indonesia", di STIE Kerja Sama, Yogyakarta, 18 Nopember 2000

Lempelius, Christian dan Gert Thoma, 1979. Industri Kecil dan Kerajinan Rakyat, LP3ES, Jakarta

Mountjoy Alan B., 1983 Indutrialisasi dan Negara-Negara Dunia Ketiga (Terj), PT. Bina Aksara, Jakarta

Setiawan Bonnie,2003." Antara Doha dan Canchun, Cengkraman 
| Industri Kecil dalam Pusaran Pasar Global

Neoliberalisme pada Tubuh WTO"

Kenichi Ohno, 2004. “Vietnam's dalam I. Wibowo dan Francis Wahono (ed), Neoliberalisme, Cindelaras, Yogyakarta

Spillane James J.,2003."Industri Ringan Kaki : Neoliberalisme dan Investasi Global", dalam Wibowo I. dan Francis Wahono (ed), Neoliberalisme, Cindelaras, Yogyakarta Industrialization Strategy in the Age of Globalization Key Issues and Policy Advice". National Economic University (NEU)/Japan International Cooperation Agency (JICA). $\quad$ www.JStore.com didownload tanggal 18 Desember 2008

Masayuki Tanimoto, 2004. "The Wiryono P.,2003."Neoliberalisme Role of Tradition in Japan's Industrialization:

dalam Industri Pangan" dalam I. Wibowo dan Francis Wahono (ed), Neoliberalisme, Cindelaras, Yogyakarta A Perspective of Indigenous Development" http://www.e.utokyo.ac.jp/cirje/research/03resear ch02dp.html didownload tanggal 1 Desember 2008 
| Lasarus Jehamat

DIMENSIA, Volume 5, No. 1, Maret 2011 | 14 